\title{
Using Nursing Theory to Improve the Teaching of Engineering Practice
}

\section{Dr. Daniel B. Oerther, Missouri University of Science \& Technology}

Professor Daniel B. Oerther, PhD, PE, BCEE, CEng, F.AAN joined the faculty of the Missouri University of Science and Technology in 2010 after ten years on the faculty of the University of Cincinnati where he served as Head of the Department of Civil and Environmental Engineering. Since 2014, he has concurrently served as a Senior Policy Advisor to the U.S. Secretary of State in the areas of environment, science, technology, and health (ESTH). Oerther earned his B.A. in biological sciences and his B.S. in environmental health engineering from Northwestern University (1995), and he earned his M.S. (1998) in environmental health engineering and his Ph.D. (2002) from the University of Illinois, Urbana-Champaign. He has completed postgraduate coursework in Microbial Ecology from the Marine Biology Laboratory, in Public Health from The Johns Hopkins University, and Public Administration from Indiana University, Bloomington. Oerther is a licensed Professional Engineer (PE, Ohio), Board Certified in Environmental Engineering (BCEE) by the American Academy of Environmental Engineers and Scientist (AAEES), and registered as a Chartered Engineer (CEng) by the U.K. Engineering Council. His scholarship, teaching, service, and professional practice focus in the fields of environmental biotechnology and sustainable development where he specializes in promoting Water, Sanitation, and Hygiene (WaSH), food and nutrition security, and poverty alleviation. Oerther's awards for teaching include the best paper award from the Environmental Engineering Division of ASEE, as well as recognition from the NSPE, the AAEES, and the Association of Environmental Engineering and Science Professors (AEESP). He participated in both the 2006 and the 2015 conferences of the National Academies Keck Futures Initiative (NAKFI) as well as the 2011 Frontiers of Engineering Education Symposium (FOEE) of the U.S. National Academies. Oerther is a four-time recipient of Fulbright, and he has been recognized with a Meritorious Honor Award by the U.S. Department of State. Due to his collaborations with nurses and healthcare professionals, Professor Oerther has been inducted as a Lifetime Honorary Member of Sigma Theta Tau, the International Honor Society of Nursing (STTI), and he has been inducted as a Lifetime Honorary Fellow of the American Academy of Nursing (F.AAN). 


\title{
Using Nursing Theory to Improve the Teaching of Engineering Practice
}

\begin{abstract}
Engineering education includes both classroom training in sciences and professional skills as well as learning-through-doing to integrate practice and engineering design into the future licensed Professional Engineer (PE). In a similar manner, nursing education includes both classroom training in sciences and professional skills as well as learningthrough doing to integrate practice and caring into the future licensed Registered Nurse $(\mathrm{RN})$. From the mid- $19^{\text {th }}$ century until modern day, the fields of environmental engineering and community health nursing have worked side-by-side to prevent disease while promoting health and wellness. This paper provides a synthesis of previously published case studies by the author documenting collaborative learning among environmental engineers and community health nurses. During a decade of working together, Florence Nightingale's Environmental Theory served as the organizing principle for teaching practice to the environmental engineers as facilitated through coaching and interaction with community health nurses. This paper provides a side-byside comparison of the professions of engineering and nursing, and includes the results of assessments using mixed methods to document the impacts of exposure to nursing practice on the formation of emergent engineers.
\end{abstract}

\section{Introduction}

Engineering education emphasizes exposure to real-world application often through experiential learning. Mentored, student design experiences, including programs such as Engineers Without Borders-USA, provide opportunities for engineering students from diverse disciplines to learn 'practice' through 'doing' both in an individual as well as in a team format. These experiences fit well within a dictionary definition of engineers, namely, "a person who has scientific training and who designs and builds complicated products, machines, systems, or structures." (Merriam-Webster). And yet, student outcomes for ABET accredited engineering programs include design within social, health, and safety constraints as well as broad education incorporating global and societal context.

While there exist a myriad of potential approaches to integrate 'practice' into the engineering curriculum, the examples available often in the engineering education literature tend to focus upon opportunities for authentic learning such as the creation of capstone projects with real world applications ${ }^{1}$ or the development and use of an overall umbrella of challenges to which engineering faculty can design lectures, course modules, or entire courses. ${ }^{2}$ A variety of examples exist for the use of public health as an authentic learning opportunity for students of engineering. ${ }^{3,4,5}$ A similar approach to integrate practice into the classroom has been attempted in parallel within the field of nursing. For example, Alexander and co-workers reported on the use of waterborne disease case 
investigation as a tool for simulating public health nursing practice. ${ }^{6}$ As described by Alexander and co-workers, the project offered a total of 157 undergraduate nursing students in a public health nursing course a chance to learn the practice of nursing in the context of helping clients to be free from illness from drinking water. ${ }^{6}$

It may be unsurprising to consider that engineers and nurses may use similar approaches - including multidisciplinary collaboration among nurses and engineers - to address authentic learning of 'practice' for both disciplines. For example, McClelland et al, reported on an educational collaboration among nursing students and engineering students to explore the development of assistive device technology to improve the health of disabled individuals. ${ }^{7}$ In fact, prior research suggests that engineering and nursing share a need for learning 'practice' through doing in three areas, namely: a) an intellectual or cognitive apprenticeship; b) a skill-based apprenticeship related to clinical judgment and practice; and c) an apprenticeship to the ethical component of behavior of the profession. ${ }^{8}$ Interestingly, what is significantly different among the professions of nursing and engineering is the degree to which students on their way to becoming practitioners demonstrate an ability to empathize with others. A comprehensive study of 1,872 undergraduate students enrolled at a large Midwestern U.S. research-university identified that nursing students have a significantly higher degree of empathy for others as compared to students in a variety of other disciplines, including engineering. ${ }^{9}$

This current study hinges upon the hypothesis that nursing theory provides a framework for engineers from multiple disciplines to improve the learning of 'practice'. A nurse is defined as, "a person who cares for the sick or infirmed who is skilled in promoting and maintaining health," (Merriam-Webster). Both nurses and engineers use science and technology. Both nurses and engineers creatively solve practical problems. But nurses focus upon the "art of caring" and the "practice of health promotion"; whereas, in contrast, engineers focus upon the "art of design" and the "practice of building". To improve the teaching of engineering practice, Florence Nightingale's environmental theory was used as a framework to guide experiential learning of multidisciplinary engineering teams working on projects in support of the United Nations Millennium Development Goals (these projects are often similar to the types of activities undertaken by student chapters of EWB-USA). Student teams worked on term-length projects, earned academic credit, and travelled abroad to collect data for design and to build new systems in developing countries. Nurses, embedded as members of these teams, exposed the engineering students to the practice of nursing to compliment and supplement the practice of engineering. The perceptions of engineering students exposed to Nightingale's environmental theory were evaluated using mixed methods including anonymous surveys as well as focus group discussions.

\section{Background}

Nightingale's Environmental Theory. As originally published by Florence Nightingale in her seminal work, "Notes on Nursing: What it is, What it is not," (1859), and as summarized in numerous, readily available sources, Nightingale's environmental theory represents the first grand theory of the modern practice of nursing (see: www.nursing- 
theory.org). The theory includes seven assumptions that focus the nurse on taking care of the patient's environment in order to achieve wellness and cure illness, namely:

1. Natural laws;

2. Mankind can achieve perfection;

3. Nursing is a calling;

4. Nursing is an art and a science;

5. Nursing is achieved through environmental alteration;

6. Nursing requires a specific educational base; and

7. Nursing is distinct and separate from medicine.

The ten environmental factors described by Nightingale include: ventilation and warming; light and noise; cleanliness of the area; health of houses; bed and bedding; personal cleanliness; variety; offering hope and advice; food; and observation. Nightingale believed that the practice of nursing was separate from the practice of medicine, and her environmental theory focused upon the patient, and identified the primary duty of the nurse to place the patient in the best possible environment for nature to act - the idea is man can cure himself if placed in an environment that promotes health. Furthermore, Nightingale was the first modern nurse to advocate for the training of nurses to put into practice these theories in a systematic manner.

Many practitioners in the field of environmental engineering point to the actions of Dr. John Snow - a physician - who removed the handle of the Broadstreet Pump in 1854 as the first act in modern environmental engineering. From these dates, Nightingale's publication of her environmental theory in 1859 and Snow's action in 1854, it is fair to presume that the modern field of nursing and the modern field of environmental engineering co-originated at approximately the same time. But, the fields of nursing and engineering are significantly different.

Comparison of the Professions of Nursing and Engineering. For example, according to 2015 data reported by the Bureau of Labor Statistics of the U.S. Department of Labor, there are a similar number of people employed in the fields of architecture and engineering as employed in the field of nursing - architecture and engineering occupations employee 3.0 million people while 3.0 million people are employed as registered nurses (http://www.bls.gov/cps/cpsaat11.htm). But, there are significant gender differences among architecture and engineering as compared to nursing architecture and engineering is only $15.1 \%$ female while $89.4 \%$ of nurses are female. And, there are significant differences in financial compensation among the field of architecture and engineering as compared to nursing - the median weekly earnings of individuals employed in full-time positions in architecture and engineering occupations was $\$ 1,424$ whereas registered nurses earned $\$ 1,116$ each week.

Interestingly, although 'engineering' is considered solidly with the umbrella of STEM in fact, the E stands for engineering - the field of nursing - although heavily dependent upon technology and math - is not always considered a part of STEM. For example, the Bureau of Labor Statistics of the U.S. Department of Labor includes nursing in its list of STEM fields. In contrast, the Economics and Statistics Administration of the U.S. Department of Commerce does not, and the Immigration and Customs Enforcement of 
the U.S. Department of Homeland Security does not include nursing on its list of STEM fields that make non-citizens eligible for a visa extension. Similarly, the National Science Foundation does not include nursing among its list of STEM fields. Thus, while nursing science is recognized as a field of rigorous research and nursing practice is increasingly evidence-based, one may speculate that the "art" of nursing may be a stumbling block to a STEM designation.

Davis provides a useful lens for evaluating the nature of occupations by examining codes of professional ethics ${ }^{10}$. While avoiding the repetition of the linguistic proof, Davis defines a profession as, "... a number of individuals in the same occupation voluntarily organized to earn a living by opening serving a certain moral ideal in a morally permissible way beyond what law, market, and morality would otherwise require." Coupled with an understanding of the meaning of the terms "code" and "ethics", Davis concludes that the "Canons of Professional Ethics" adopted by the American Bar Association in 1908 represent the first code while "Principles" adopted by the American Medical Association in 1912 represents the first code within the healthcare occupations. A comparison among the codes of professional ethics among engineering and nursing is useful for understanding the similarities and the differences among the 'practice' of the two professions.

The Code of Ethics for Nurses with Interpretive Statements was most recently revised and adopted by the American Nursing Association in 2015 and is based upon the evolution of the first formal code of ethics for nurses adopted in 1950 (http://www.nursingworld.org/MainMenuCategories/ANAMarketplace/ANAPeriodicals/ OJIN/TableofContents/Vol-20-2015/No2-May-2015/The-Nursing-Code-of-Ethics-ItsValue-Its-History.html?css=print). The first provision of the ANA Code of Ethics states, "The nurse practices with compassion and respect for the inherent dignity, worth, and unique attributes of every person." Webster's dictionary defines empathy as, "the action of understanding, being aware of, being sensitive to, and vicariously experiencing the feelings, thoughts, and experiences of another...," and it defines compassion as, "sympathetic consciousness of others' distress together with a design to alleviate it." Thus, it is clear that first and foremost within the ethical practice of nursing is the necessity to practice empathy.

The Code of Ethics for Engineers was most recently revised and adopted in 2007 and is based upon the evolution of the first formal code of ethics for engineers introduced in the May, 1935 issue of The American Engineer in a form of a suggestion for membership consideration (https://www.nspe.org/resources/ethics/code-ethics/history-code-ethicsengineers). The first fundamental canon of the NSPE Code of Ethics states, "Engineers, in the fulfillment of their professional duties, shall: hold paramount the safety, health, and welfare of the public." Webster's dictionary defines the public as, "of, relating to, or affecting all the people or the whole area of a nation or state." Thus, while the first statement in the ethical practice of nursing necessitates an interpersonal connection between the physical, mental, and emotional state of the nurse and every person, the ethical practice of engineering begins with a focus upon the more metaphysical and detached notion of 'the public'. 


\section{Application of Nursing Theory to Engineering Education Emphasizing Two Courses}

To explore the apparent disconnect among the 'practice' of engineering and the 'practice' or nursing as reflected in the professional codes focused upon 'every person' as compared to 'the public' for nursing and engineering, respectively, Nightingale's environmental theory was used as a starting point for interdisciplinary discussion among engineering students and nursing students who participated side-by-side in a series of educational offerings over a period of approximately ten years. As described in Table 1, six seminal events - including instruction in two separate courses - over a period of approximately one decade were instrumental in the development of this body of

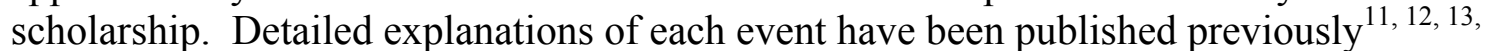
$14,15,16,17,18,19,20,21$ but a brief description of the two courses included in the table CEE600 MDG7: Ensuring Environmental Sustainability and CE390/CE4099 Undergraduate Research - is offered for clarification as an example of the types of activities undertaken during the decade of co-learning among engineers and nurses.

CEE600 MDG7: Ensuring Environmental Sustainability. An experimental course entitled, "CEE600 MDG7: Ensuring Environmental Sustainability," was developed and offered as a dual-level (graduate and undergraduate), term-length offering that included an optional visit abroad to India for students at the University of Cincinnati, Ohio, USA. The course description stated, "The objective of this course is to demonstrate key concepts in environmental chemistry and microbiology through engaging students in the evaluation of appropriate technology using case studies. Drinking water and sanitary system design in North America, India, and Sub- Saharan East Africa will be used to compare design needs in developed, emerging, and less developed countries. Successful completion of this course should prepare students for further study in appropriate technologies." Through a dual listing with the campus-wide honors program, this course was successfully marketed as an elective to students in a wide range of disciplinary backgrounds including engineering, nursing, business, and design.

CE390 or CE4099 Undergraduate Research. Undergraduate, independent research through a course entitled, "CE390 or CE4099 Undergraduate Research," has been offered to undergraduate students as a term-length opportunity to engage independent research under the mentorship of a faculty advisor at the Missouri University of Science and Technology, USA. The course description states, "Designed for the undergraduate student who wishes to engage in research. Not for graduate credit. Not more than six (6) credit hours allowed for graduation credit. Subject and credit to be arranged with the instructor." Through word of mouth as well as recruitment of interested students, this course was successfully marketed as an elective to students with a variety of long-term career objectives including premedical students pursuing a baccalaureate in environmental engineering. 
Table 1. Summary of six seminal learning opportunities including a course at the University of Cincinnati (CEE600) and a course at the Missouri University of Science and Technology (CE390/CE4099).

\begin{tabular}{|c|c|c|}
\hline $\begin{array}{l}\text { Description; } \\
\text { Time frame }\end{array}$ & Co-leaners & Outcome(s) \\
\hline $\begin{array}{l}\text { CEE600 MDG7: Ensuring } \\
\text { Environmental } \\
\text { Sustainability (dual-level, } \\
\text { term-length course) } \\
\text { Autumn, } 2004 \text { - Autumn, } \\
2009^{11}\end{array}$ & $\begin{array}{l}\text { Author } \\
3 \text { additional faculty } \\
\text { approx. } 80 \text { undergraduate } \\
\text { and } 40 \text { graduate students }\end{array}$ & $\begin{array}{l}\text { Development and delivery } \\
\text { of a term-length, dual-level } \\
\text { course with two trips } \\
\text { abroad to India }\end{array}$ \\
\hline $\begin{array}{l}\text { Formation of student } \\
\text { chapter of Engineers } \\
\text { Without Borders } \\
\text { August, } 2006 \text { - April, } \\
2009^{12,13,14}\end{array}$ & $\begin{array}{l}\text { Author } \\
18 \text { undergraduate students } \\
\text { the village of Kamunga, } \\
\text { Kenya }\end{array}$ & $\begin{array}{l}\text { Two trips to Kenya } \\
\text { Construction of a water } \\
\text { distribution system serving } \\
1,000 \text { villagers }\end{array}$ \\
\hline $\begin{array}{l}\text { Growth of Okkullo Family } \\
\text { Foundation } \\
\text { April, 2009-present }\end{array}$ & $\begin{array}{l}\text { Author } \\
5 \text { members of the Okkullo } \\
\text { family } \\
\text { the village of Kamunga, } \\
\text { Kenya }\end{array}$ & $\begin{array}{l}\text { Creation of the equivalent } \\
\text { of a } 501 \mathrm{C} 3 \text { non government } \\
\text { organization }\end{array}$ \\
\hline $\begin{array}{l}\text { US EPA People, Planet, and } \\
\text { Prosperity competition } \\
\text { Spring } 2005 \text {, Spring } 2006^{15}\end{array}$ & $\begin{array}{l}\text { Author } \\
2 \text { additional faculty } \\
10 \text { undergraduate and } 2 \\
\text { graduate students }\end{array}$ & $\begin{array}{l}\text { Two trips to Washington, } \\
\text { DC }\end{array}$ \\
\hline $\begin{array}{l}\text { Creation of PulaCloud, LLC } \\
\text { Summer, } 2012 \text { - Spring, } \\
2015^{16}\end{array}$ & $\begin{array}{l}\text { Author } \\
4 \text { corporation co-founders } \\
7 \text { villagers from Kamunga, } \\
\text { Kenya }\end{array}$ & $\begin{array}{l}\text { Creation of a Limited } \\
\text { Liability Corporation with } \\
\$ 55,000 \text { in revenue }\end{array}$ \\
\hline $\begin{array}{l}\text { CE390/CE4099 } \\
\text { Undergraduate Research } \\
\text { (free elective, term-length } \\
\text { course) } \\
\text { Summer, } 2011 \text { - } \text { present }^{11} \text {, } \\
17,18,19,20,21\end{array}$ & $\begin{array}{l}\text { Author } \\
11 \text { undergraduate and } 2 \\
\text { graduate students } \\
150 \text { nursing students in } \\
\text { India }\end{array}$ & $\begin{array}{l}\text { Development and delivery } \\
\text { of term-length course with } \\
\text { two trips to Kenya, one trip } \\
\text { to India, on trip to } \\
\text { Guatemala, and one trip to } \\
\text { Brazil }\end{array}$ \\
\hline
\end{tabular}


From the U.S., approximately 120 undergraduate students and nearly 50 graduate students have gained classroom knowledge about Nightingale's environmental theory through these six seminal learning activities. More than 25 U.S. students have travelled to Kenya. More than 25 U.S. students have travelled to India. And more than 25 U.S. students have travelled either to Washington, DC, Guatemala, or Brazil. In addition, multiple faculty have taken part in these sixe seminal learning activities, professionals have been trained in the U.S., villagers have participated actively overseas, and more than 150 nursing students in India have directly benefitted from these projects. Collectively, the overall impact of these educational activities has been profound for a large cohort of multidisciplinary individuals.

\section{Results of Assessments for Two Courses}

Table 2 presents partial results of anonymous surveys conducted at the end of each semester offerings of CEE600 MDG7: Ensuring Environmental Sustainability. The results indicate an overall high quality experience, but with some significant variation among different cohorts. For example, the scores for the course offering in the Autumn of 2009 were significantly lower as compared to the scores for the course offering in the Autumn of 2008. While the students were different for each offering, the composition of the multidisciplinary teams was similar - engineers, nurses, pre-med, design, business, and other disciplines all participated. Both offerings included ten weeks of lecture followed by two weeks of overseas travel. The survey results presented in Table 2 were collected following the return from the overseas trip. On November 26, 2008, approximately one month before departure from the U.S. to India, a group of terrorist attacked a variety of targets in Mumbai, India. The students participating in the Autumn 2008 study abroad trip expressed solidarity with the country about which they had been studying, and through the free-response to open-ended, anonymous surveys this group of students from the U.S. viewed a trip to India on the heels of the terrorist attacks as a sign of solidarity (data not shown). In contrast, the team of students from the U.S. who visited India in the Autumn of 2009 did not have a similar rallying cry. Instead, these students experienced culture shock typical for many who travel overseas for their first time to a developing country. Furthermore, in the Autumn of 2009, one of the U.S. students suffered from a serious medical condition, and although the overall trip was not negatively impacted, the results of open-ended, anonymous surveys suggested that students in the Autumn of 2009 experienced 'disappointment' because of the hardships of travel and the need to take care of one member of the travelling team (data not shown).

Figure 1 provides representative photographs of participants in a variety of settings from across the six activities reported in Table 1. Individual case studies of the results of each of the activities reported in Table 1 have been published separately in a number of

venues. ${ }^{11,12,13,14,15,16,17,18,19,20,21}$ Rather than re-summarize each of these previously published case studies, a representative account of the similarities between CEE600 MDG7: Ensuring Environmental Sustainability and CE390/CE4099 Undergraduate Research is provided below. 
Table 2. Summary of anonymous, paper-based surveys of enrolled students in CE600 at the end of the term. (Likert scale results; 5 is strongly agree with the statement; 1 is strongly disagree with the statement)

\begin{tabular}{|c|c|c|c|c|c|c|c|}
\hline & \multicolumn{7}{|c|}{ Question } \\
\hline Term & 1 & 2 & 3 & 4 & 5 & 6 & 7 \\
\hline Aut '04 & 3.9 & 4.6 & 4.8 & 3.7 & 3.4 & 4.1 & 4.3 \\
\hline Aut '05 & 3.8 & 4 & 5 & 4.6 & 2.3 & 4.2 & 5 \\
\hline Aut '06 & 4.3 & -- & -- & 3.2 & 3.2 & 3.3 & 3.3 \\
\hline Aut '07 & 4.2 & -- & -- & 4.1 & 2.9 & 4.3 & 4.6 \\
\hline Aut '08 & 4.6 & 4.6 & 4.7 & 4.5 & -- & 4.8 & 4.9 \\
\hline Aut '09 & 3.9 & 4.8 & 4.4 & 4 & -- & 3.9 & 4.1 \\
\hline
\end{tabular}

Note: -- indicates that the question was not asked.

Statements:

1. The course was well planned and organized

2. The course material related to my profession

3. The professor emphasized analytical thinking

4. Assessment tools were fair

5. Reading materials were appropriate

6. The course was excellent

7. The professor was excellent

\section{Qualitative Results from Two Courses Linking Engineering and Nursing Practice in India Over a Series of Activities From 2007 Through Present}

To educate students in professional practice, engineers, nurses, and others from 'developed' countries often travel to 'developing' countries to participate in 'hands-on' learning. The central challenge of these trips is to ensure adequate opportunities for student learning while simultaneously ensuring that the economic asymmetry between the travellers and the hosts is not exploited to the detriment of either. In 2007, a partnership was formed among an educational institution in the U.S. and NM Sadguru (a nongovernmental organization based within India). In its first year of collaboration, the U.S. team integrated the disciplines of engineering, business, science, and design to create interventions to improve economic opportunity for rural villagers. During the first trip to India, it became immediately apparent that the U.S. team lacked a framework for assessing the health benefits of proposed interventions. To address this shortcoming, nursing professionals were recruited to be part of the second year of the course and to actively participate in the second study-abroad trip to India. Through classroom lectures and small group discussions, the importance of considering environmental health using the framework originally developed by Nightingale was explored. The original team from the U.S. reached out through a collaborative nursing network to identify nurse educator and nursing students within India to participate during the second study-abroad visit. This intentional choice - inviting nurses from India to participate in the project - 
Figure 1. Representative photographs (a India 2007; b, c India 2009; d Kenya 2007; e, f Kenya 2008; g, h Kenya 2012; i Washington DC 2005; j, k Kenya 2011; 1 India 2012; m, n India 2013; o Brazil 2013)
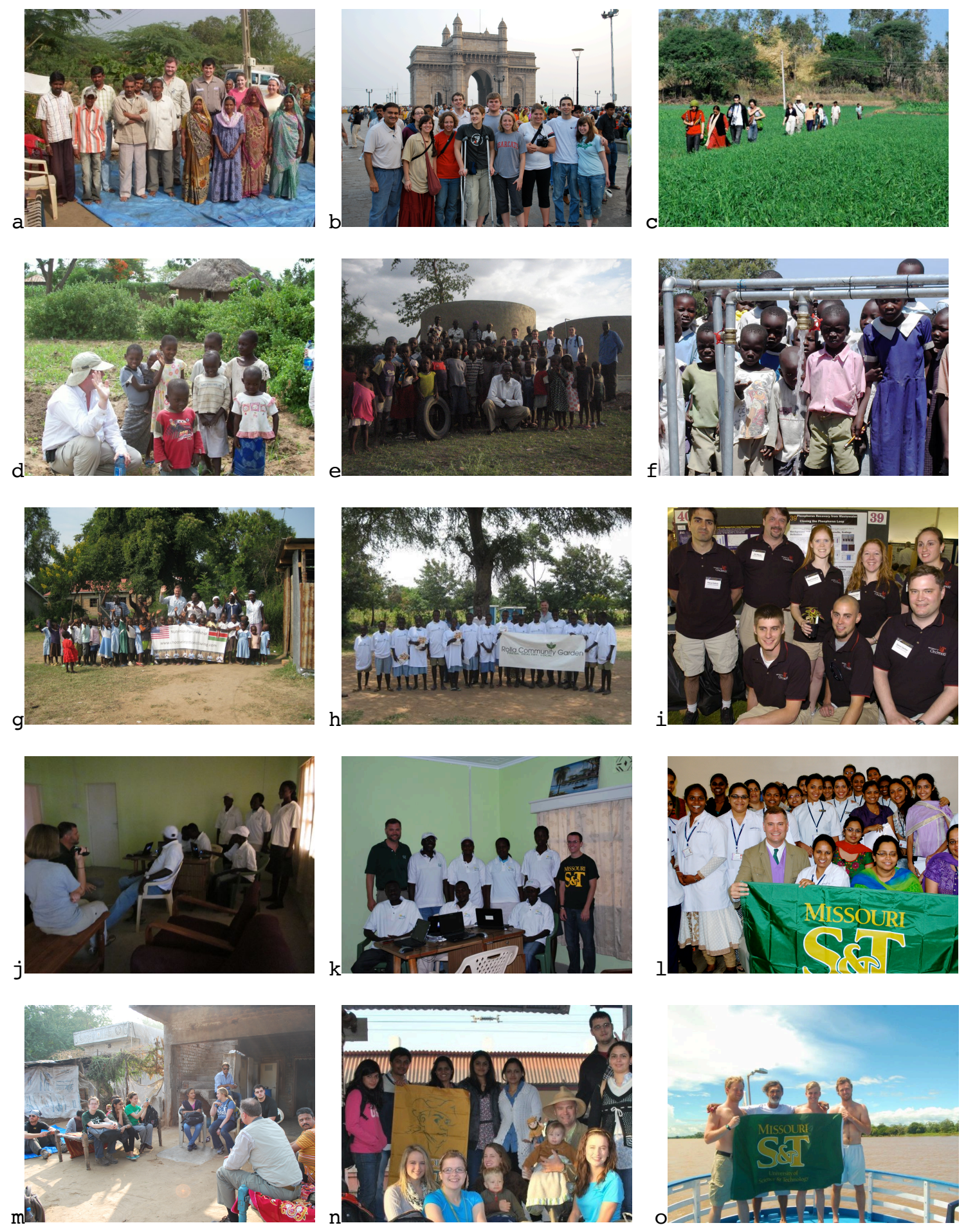
allowed the team from the U.S. the opportunity for explore both cross-cultural and crossdisciplinary collaborations.

The mandate of NM Sadguru is focused upon watershed management, rural development, organic farming, agroforestry, indigenous rights, and women's rights. The team of students traveling from the U.S. divided into small groups to address each of these topics. Simultaneously, two nurses from India were recruited to join the team of U.S. students when they visited for study abroad. The goal was to use native nursing students as 'cultural translators' that were also equipped with a deep understanding of and appreciation for the use of Nightingale's environmental theory. At the end of the two weeklong study-abroad experiences, one of the Indian nurses reflected, "In innumerable ways I benefited personally as well as professionally from this trip. We conducted household surveys including the health and agricultural aspect of the villagers. We did water testing from the lake, hand pumps, and wells. We educated villagers about health aspects of water and sanitation and also about drip irrigation and composting. Anthropometric measurements were performed on school children to assess their nutritional status. We presented the health aspects of the project to the community leaders of the village. Our best experience of the trip was when we informed the community about elevated nitrate levels in one drinking water well." During the study abroad, the U.S. students and the nursing students completed a survey of water supplies, specifically searching for traces of nitrate fertilizer potentially contaminating ground water in the primary agricultural area. Elevated levels of nitrate in drinking water can cause Blue Baby Syndrome in infants. As documented in the reflection from the Indian nurse, "The level [of nitrate] for this community was greater than $50 \mathrm{mg}$ nitrate-nitrogen per liter. In the United States, if the level is over $10 \mathrm{mg}$, everything is shut down and alternative water supplies are identified to protect the health of infants. We helped inform the community of the health risks, and the community responded by immediately discontinuing use of the well. The local NGO will start to work on educating this community about the risk of disposing of fertilizers near wells. It was very encouraging to work with U.S. students and we were surprised with their friendly and extremely warm welcoming behavior. We have learned lot of things while working with the other disciplines, especially that it creates innovative ideas which can't be created if people from the same base of knowledge work on a problem. Also, it gives ideas about the way a person from different disciplines address a problem. For example, the way of looking at a problem of business student is different from the engineering student." Interestingly, in response to open-ended questions about the 'best' part of the trip, the U.S. students indicated that the best part of the trip was their interactions with these two nurses from India - because the nurses were able to provide cultural insight into the project and to explain health from an Indian's point of view.

Building upon the success of the multidisciplinary and cross-cultural experience with NM Sadguru, a team of U.S. students was selected to participate in a study abroad trip to work alongside both environmental science students from India as well as additional nursing students from India. After this trip, a U.S. engineering student reflected, "I feel that through the research and working in a team atmosphere (with me being the only American in the group) helped me grow as a professional. Yes, I have worked in teams 
before, but not in a team of all Indians and me! At first, my team and I were on two different tracks with the research, especially me trying to understand fully what their goals were, but after taking the afternoon off and grabbing ice cream and brownies just to create team chemistry, we were able to achieve a common goal! I know that after this semester I am excited to take these skills I learned, while in India, to my internship this summer." Another U.S. engineering student reflected, "The language barrier while working with farmers also presented a challenge. It taught me a lot of patience and trust in the rest of my group as we worked to get surveys answered and questions conveyed correctly. Questions needed to be asked different ways to make sure everything was understood and nothing was accidentally left out. As there were several different backgrounds within the group (nursing, engineering, and science), it was an inspiring and informative experience to see each of us present new ideas or questions that were unique to each of our field. Having a well-rounded group helped me to learn more and I think helped to broaden the views that each of us brought individually."

\section{Conclusion}

Nightingale's environmental theory took nursing beyond the bedside to focus on how to improve the environment around the patient. By placing Nightingale's approach at the center of interdisciplinary interaction among nurses and engineers, the nurses benefitted from understanding why very minuscule detailed of chemical measurements are so critical to environmental health (i.e., the importance of measuring nitrate in drinking water supplies), and engineers benefitted from understanding that a holistic view of a community must include "not only a detailed study of the trees but also an understanding of the forest".

The synthesis presented in this paper is original because it is not a simple report of a case study or an example of well-described pedagogical approaches. Rather this work introduces and evaluates the value inherent in using a guiding theory - in this case Nightingale's environmental theory - as the overarching theme to teach students about the practice of engineering. Similarities among 'practice' from diverse - yet strangely similar fields - including nursing - offer a unique opportunity for engineering faculty to train our students as 'practitioners'.

\section{References}

1. Powell, R. (2005, June), Integrating Practice Into Engineering Education Paper presented at 2005 Annual Conference, Portland, Oregon. https://peer.asee.org/14209

2. Huettel, L., Gustafson, M. R., Nadeau, J. C., Schaad, D., Barger, M. M., \& Linnenbrink-Garcia, L. (2015, June), A Grand Challenge-based Framework for Contextual Learning in Engineering: Impact on Student Outcomes and Motivation Paper presented at 2015 ASEE Annual Conference \& Exposition, Seattle, Washington. 10.18260/p.23389

3. Pumphrey, S., Hoessle, A., \& Oerther, D. (2006, June), Service Learning At Cincinnati: Researching Water Treatment For Emerging Economies Paper presented at 2006 Annual Conference \& Exposition, Chicago, Illinois. https://peer.asee.org/58 
4. White, C., Crawford, R., Wood, K., \& Talley, A. (2010, June), Influences And Interests In Humanitarian Engineering Paper presented at 2010 Annual Conference \& Exposition, Louisville, Kentucky. https://peer.asee.org/16050

5. $\quad$ Farris, J. P. (2013, June), Water Filters in Ghana: An Exploration of the Technology and Education that is Required for Sustainable Development at the Base of the Economic Pyramid Paper presented at 2013 ASEE Annual Conference \& Exposition, Atlanta, Georgia. https://peer.asee.org/22746 6. $\quad$ Alexander, G.K., Canclini, S.B., Fripp, J., \& Fripp, W. (2017), Waterborne Disease Case Investigation: Public Health Nursing Simulation Journal of Nursing Education 56(1):39-42

7. McClelland, M., \& Kleinke, D. (2013), Improving Lives Using Multidisciplinary Education: Partnering to Benefit Community, Innovation, Health, and Technology Journal of Nursing Education 52(7):406-409

8. $\quad$ Noone, J. (2009), Teaching the Three Apprenticeships: Designing Learning Activities for Professional Practice in an Undergraduate Curriculum Journal of Nursing Education 48(8):468-471

9. $\quad$ Penprase, B., Oakley, B., Ternes, R., \& Driscoll, D. (2013), Empathy as a Determining Factor for Nursing Career Selection Journal of Nursing Education 52(4):192-197

10. Davis, M. (2003), What can we learn by looking for the first code of professional ethics? Theoretical Medicine and Bioethics 24(5): 433-454.

11. Oerther, S.E., Manjrekar, P., \& Oerther, D.B. (2014), Utilizing Mobile Health Technology at the Bottom of the Pyramid Procedia Engineering 78:143-148

12. Kukreti, A., McNerney, P., Soled, S., Obarski, K., Lu, M., \& Miller, R., Oerther, D., Wei, H., \& Fowler, T. (2006, June), An Engineering Research Experience For Teachers: Implementation And Assessment Paper presented at 2006 Annual Conference \& Exposition, Chicago, Illinois. https://peer.asee.org/360

13. Pumphrey, S.I., Divelbiss, D.W., \& Oerther, D.B. (2006), Appropriate Technology for the Treatment of Drinking Water in Roche, Tanzania in Recent Progress in Slow Sand and Alternative Biofiltration Processes published by International Water Association ISBN: 9781843391203

14. Hadaway, L., Urbaitis, M., Lamendella, R., Oerther, D., Burrows, A., Borowczak, M., \& Kukreti, A. (2010, June), Engineering Education Collaboration: Innovative Pedagogical Methods For High School And University Environmentalists Paper presented at 2010 Annual Conference \& Exposition, Louisville, Kentucky. https://peer.asee.org/16896

15. Oerther, D., Carlarne, C., Maurer, E., Lamendella, R., \& Pumphrey, S. (2006, June), Using Phosphorus Recovery From Wastewater As A Context For Teaching Sustainable Development With Usepa P3 Support Paper presented at 2006 Annual Conference \& Exposition, Chicago, Illinois. https://peer.asee.org $/ 60$

16. Schriner, A., Oerther, D.B. (2014), No Really, (Crowd) Work is the Silver Bullet Procedia Engineering 78:224-228

17. Divelbiss, D.W., Boccellii, D.L., Succop, P.A., \& Oerther, D.B. (2013), Environmental Health and Household Demographcs Impacting Biosand Filter Maintenance and Diarrhea in Guatemala: An Application of Structural Equation Modeling Environ Sci \& Technol 47(3):1638-1645

18. Oerther, D.B., \& Oerther, S.E. (2013), Teaching the MDGs: The Role of the Nurse in Multidisciplinary Project Based Instruction Paper presented at 2013 Biennial Conference of Sigma Theta Tau, the International Honor Society of Nursing (STTI), Indianapolis, Indiana.

http://www.nursinglibrary.org/vhl/bitstream/10755/308620/1/oerther+STTI+presentation+november+2013 +teaching+the+MDGs.pdf

19. Oerther, D.B. (2015), World Hunger, Food Deserts, and Meatless Mondays Reflections on Nursing Leadership 41(1) https://www.reflectionsonnursingleadership.org/features/morefeatures/Vol41_1_world-hunger-food-deserts-and-meatless-mondays 20. Oerther, D.B. (2016), The Fulbright Program at 70 Years Old Environmental Engineer and Scientist 52(3):20-21

21. Oerther, D.B. (2016), From Disaster to Development: Finance Provides a Platform to Empower Technology for Resilience to Climate Change Procedia Engineering 159(2016):267-271 